\title{
Group size and composition of Tursiops truncatus (Cetacea: Delphinidae) in a coastal insular habitat off southeastern Brazil
}

\author{
Liliane Lodi * \\ Cassiano Monteiro-Neto \\ Pós Graduação em Biologia Marinha, Departamento de Biologia Marinha, \\ Universidade Federal Fluminense, Caixa Postal 100644, CEP 24001-970, Niterói - RJ, Brazil \\ * Autor para correspondência \\ lilodi@uninet.com.br
}

Submetido em 10/08/2011

Aceito para publicação em 03/01/2012

\section{Resumo}

Tamanho e composição de grupo de Tursiops truncatus (Cetacea: Delphinidae), em um habitat insular costeiro no sudeste do Brasil. O objetivo do presente estudo foi descrever o tamanho e a composição de grupo do golfinho-nariz-de-garrafa-comum (Tursiops truncatus) no Arquipélago das Cagarras ( $23^{\circ} 01^{\prime} \mathrm{S}, 43^{\circ} 12^{\prime} \mathrm{W}$ ), Rio de Janeiro, Brasil, baseado em um período de estudo de seis anos (2004 e 2006 a 2010). O tamanho dos grupos $(\mathrm{n}=51$ ) variou entre três e 30 indivíduos (média 13,7 $\pm 7,1)$ e sua frequência de distribuição apresentou duas modas: grupos de seis e 19 indivíduos. O maior tamanho médio de grupo ocorreu em 2004 (média 21,4 $\pm 3,3$ ) e o menor em 2008 (média 4,4 $\pm 0,8$ ). O número de indivíduos/grupo diminuiu ao longo dos anos o que pode estar correlacionado com a qualidade do habitat. O número médio de indivíduos imaturos (neonatos, filhotes e juvenis) expresso como a proporção do tamanho total de grupo variou entre 0,31 (2006) e 0,4 (2010). Esta proporção não variou significativamente entre os anos. Estes resultados sugerem que o Arquipélago das Cagarras deve ser considerado como hábitat crítico para sobrevivência e/ou crescimento populacional de $T$. truncatus no sudeste do Brasil.

Palavras-chave: Arquipélago das Cagarras; Golfinho-nariz-de-garrafa-comum; Residentes sazonais

\section{Abstract}

The aim of the present study was to describe the size and composition of groups of common bottlenose dolphins (Tursiops truncatus) in the Cagarras Archipelago $\left(23^{\circ} 01^{\prime} \mathrm{S}, 43^{\circ} 12^{\prime} \mathrm{W}\right)$, Rio de Janeiro, Brazil based on six years of observation (2004 and 2006 to 2010). The group size $(\mathrm{n}=51)$ ranged between three and 30 individuals (mean $=13.7 \pm 7.1$ ), and the frequency distribution of group size showed modes at six individuals and 19 individuals. The largest average group size occurred in 2004 (mean $21.4 \pm 3.3$ ) and the smallest in 2008 (mean $4.4 \pm 0.8$ ). The number of individuals/group decreased over the years and this decrease could be correlated with habitat quality. The average number of immature individuals (neonates, calves and juveniles), expressed as a proportion of the total group size, varied between 0.31 (2006) and 0.4 (2010). This proportion did not vary significantly among years. These results suggest that the Cagarras Archipelago should be considered critical habitat for the survival and /or population growth of T. truncatus in southeastern Brazil.

Key words: Cagarras Archipelago; Common bottlenose dolphin; Seasonal residents 


\section{Introduction}

Gregarious species often form highly complex societies. This societies offer increased protection, improve the utilization of available resources and allow the maximization of reproductive success (PARRISH; EDELSTEIN-KESHET, 1999).

Animal groups may vary in form, size, extent and complexity. In fact, Breder (1954) suggested that the characteristics of such groups reflect an equilibrium between environmental attraction and repulsion that is primarily associated with feeding and predatory strategies. The balance between these factors results in an optimal group size, and individuals must decide to whether to join a specific group to maximize the benefits resulting from their particular abilities (GYGAX, 2002; GOWANS et al., 2008).

The common bottlenose dolphin, Tursiops truncatus (Montagu, 1821) is a highly social species that forms groups of up to 20 animals, although larger oceanic groups of hundreds of animals may be observed (CONNOR et al., 2000). Dolphin group sizes in coastal areas may vary because the animals live in an open society characterized by fission-fusion, i.e., the grouping patterns change constantly in space and time (CONNOR et al., 2000). This social structure facilitates important learning abilities such as those related to feeding, reproduction, defense, and, communication (BRÄGER et al., 1994). In this species, group composition has been related to individual age and reproductive condition. The basic social unit consists of the following types of groups: 1) immature individuals, including subadult males and females and maturing males; 2) adult males (showing different levels of alliance formation); 3 ) adult females without calves and receptive females; and 4) pregnant females and females with calves (WELLS et al., 1987; WELLS, 1991; CONNOR et al., 2000 and references therein).

The available information on common bottlenose dolphins occurring in the coastal waters of Rio de Janeiro State, southeastern Brazil, is scarce and limited primarily to records of sightings (RAMOS et al., 2010), strandings (GEISE; BOROBIA, 1988; OLIVEIRA et al., 1994), biological data on age and growth (SICILIANO et al.,
2007) and diet (Di BENEDITTO et al., 2001). To date, our knowledge of the life history and behavior of $T$. truncatus is based on isolated and opportunistic records rather than on data from focused long-term studies.

Common bottlenose dolphins occur in the Cagarras Archipelago during the austral winter and spring, forming a seasonal resident group in the area (LODI, 2009). In contrast, the species occurs throughout the year in other coastal habitats despite seasonal variation in abundance. For example, this common pattern of occurrence is found in the Adriatic Sea (BEARZI et al., 1997; FORTUNA, 2006), the United States (SHANE, 2004), Venezuela (OVIEDO; SILVA, 2005), and Santa Catarina Island, Brazil (FLORES; FONTOURA, 2006; WEDEKIN et al., 2008).

The aim of this study was to characterize the group size and composition of $T$. truncatus inhabiting the Cagarras Archipelago on a seasonal basis, to determine whether the number of dolphins is stable, increasing, decreasing or changing in composition over the years. On April 13, 2010, a marine protected area, the Monumento Natural do Arquipélago das Ilhas Cagarras, was created by Federal Law no. 12229. Therefore, the information presented in this report may be of fundamental importance for providing baseline data for the establishment of a management plan for this marine protected area.

\section{Materials and Methods}

\section{Study area}

The Cagarras Archipelago $\left(23^{\circ} 01 \mathrm{~S}-43^{\circ} 12^{\prime} \mathrm{W}\right.$; $23^{\circ} 03^{\prime} \mathrm{S}-43^{\circ} 12^{\prime} \mathrm{W}$ ) is approximately three kilometers from the beach of Ipanema, State of Rio de Janeiro, southeastern Brazil (Figure 1) and comprises three main islands (Ilha Das Palmas, Ilha Cagarras Grande and Ilha Comprida), three small islands and seven rocky outcrops. The inner area of the archipelago is approximately $2.39 \mathrm{~km}^{2}$ (Nautical Chart No. 1501, da Diretoria de Hidrografia e Navegação da Marinha do Brasil) and the average water depth varies between 2 and $18 \mathrm{~m}$. 
FIGURE 1: Map showing the geographic location of the Cagarras Archipelago, in relation to Guanabara Bay and the southeastern Brazilian coast.

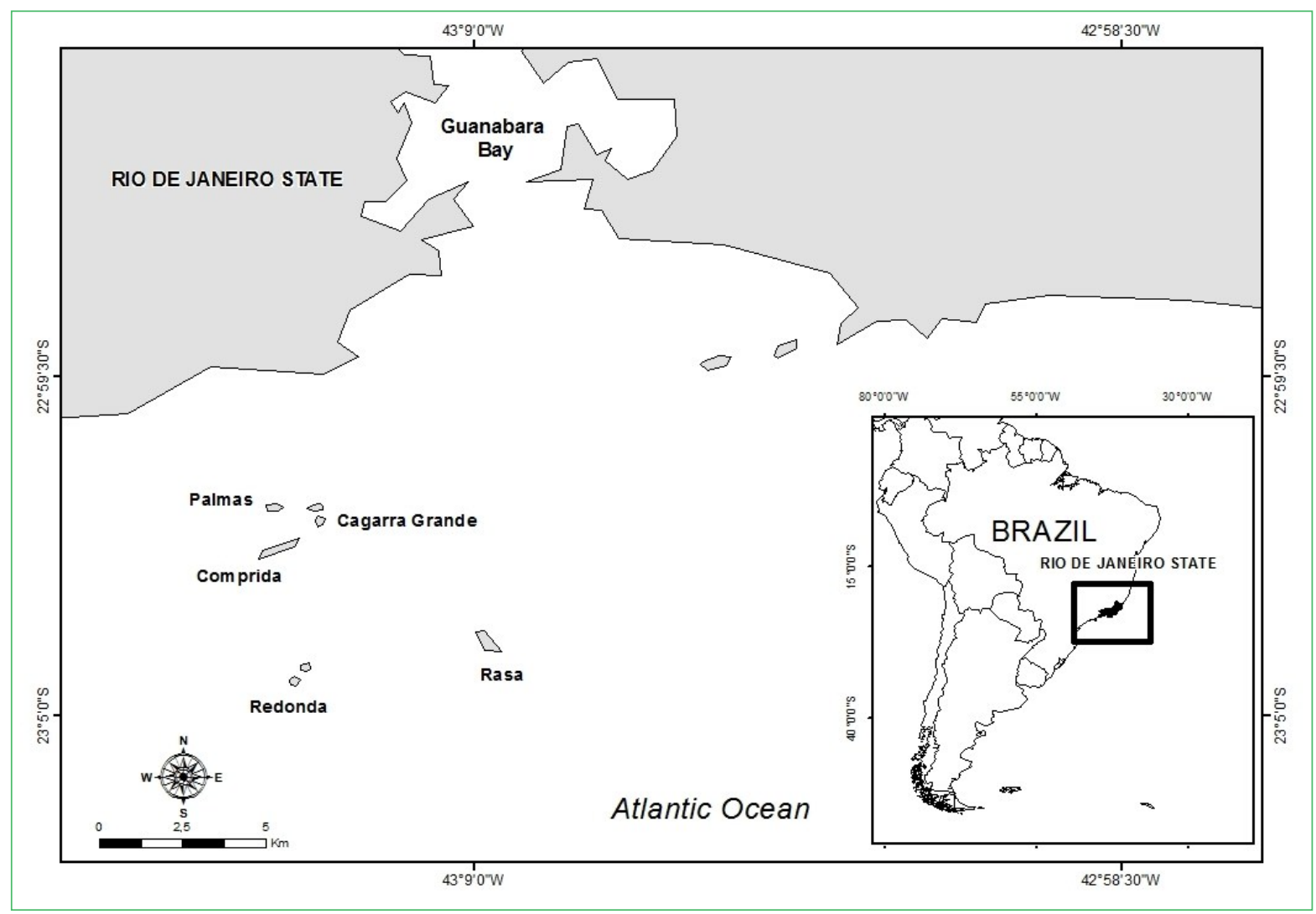

\section{Field procedures}

We conducted weekly census between August and November in 2004, 2006 and 2010 and between August and October in 2007 to 2009. The observations were made from 9:00 to 15:00h under favorable environmental conditions (Beaufort scale $\leq 2$ ). Because common bottlenose dolphins occur during the austral winter and spring in the Cagarras Archipelago (BARBOSA et al., 2008; LODI, 2009), the sampling effort was concentrated in these seasons. We focused our censuses on the interior part of the insular complex, an area of approximately $2.39 \mathrm{~km}^{2}$ easily covered by boat in a short time (Figure $1)$. The area was fully scanned and covered during each census event.

The data were recorded by a single observer on a $10 \mathrm{~m}$ diesel trawler or a $9.3 \mathrm{~m}$ motor-powered sailboat. When dolphins were sighted, we reduced the boat speed and set a course to approximate but not intercept the animal's route. Rapid or erratic changes in the speed or direction of the boat were avoided to minimize disturbance. The same boat captain was in command in all census years to minimize the variability of the boat operations.

The individuals sighted were classified into four age categories based on their behavior and size estimates (BEARZI et al., 1997; MANN; SMUTS, 1998; CONNOR et al., 2000; MANN et al., 2000; QUINTANA-RIZZO; WELLS, 2001; CAMPBELL et al., 2002): (a) neonate $-<1 / 3$ of adult size, presence of fetal folds, immature swimming, stereotyped surface respiration, frequent and non-coordinated head-butting against the water; (b) calf $-1 / 2$ of adult size, typical dislocation behind the dorsal fin of the presumed mother; (c) juvenile $-2 / 3$ of adult size; and (d) adult approximately $3 \mathrm{~m}$ in length.

In the present study, we define a group as "all dolphins sighted within a $50 \mathrm{~m}$ radius, distributed in a cohesive manner, exhibiting coordinated behavior, 
suggesting the same activity pattern" (adapted from LUSSEAU et al., 2003). Previous observations in the area (LODI et al., 2008) indicated that sighted individuals co-occurred during census events within years. These observations suggested the behaviour of a group and did not appear to represent aleatory sightings of single individuals.

We recorded the total size and composition of the groups by performing direct counts in individuals twice daily (morning and afternoon) during each census to confirm the total number of common bottlenose dolphins. The counts were further reconfirmed in the laboratory with video tape recordings (Sony Handycam Hi-8 DCR-TRV330 and mini-DV DCR-HC26). Group size was determined from the daily total number of individuals, including neonates, calves, juveniles and adults.

\section{Data analysis}

To analyze the annual patterns of group size and composition, the data were divided into six time periods (2004 through 2010, excluding 2005). We used a linear regression model on $\log$ transformed $\left(\log _{10}\right)$ group size data to test the stability of group size over different years.

The average number of immature individuals (neonates, calves and juveniles) in relation to the total number of individuals observed in the group per day of observation was calculated, and tested among years with a Kruskal-Wallis procedure in Statistica 7.0 (STATSOFT, Inc., 2004) because the data did not meet the criteria for ANOVA after transformation.

\section{Results}

A total of 65 censuses were conducted in the Cagarras Archipelago from August through November during 2004, 2006 and 2010 and from August through October during 2007, 2008 and 2009 (Table 1). During $51(78.5 \%)$ of these censuses, groups of common bottlenose dolphins were sighted in the study area. In all, $219 \mathrm{~h}$ of direct observations were collected.

\section{Group size}

Group size ranged from three to 30 individuals, with an average overall group size of $13.7( \pm 7.1$; median 16 ; mode 5). The largest mean group size occurred in 2004 (21.4) and the smallest in 2008 (4.4) (Table 1). The group size and composition did not vary between the morning and afternoon counts.

The frequency of groups of different sizes showed two modes, one at six individuals per group and the other at 19 (Figure 2). Figure 3 shows that the group size decreased over the years.

\section{Group composition}

Neonates were observed on 16 different censuses, usually during the spring (94\%). During 2004, 2006, and 2007 through 2010, calves and/or juveniles were observed in all years except during 2008, when only adults were sighted. The groups never included more than one neonate, but all groups with a neonate also included two to seven calves and two to six juveniles. The number of calves was always greater than that of

TABLE 1: Summary information on annual field census effort, total groups, encounter rate, and group size and composition.

\begin{tabular}{|c|c|c|c|c|c|c|c|}
\hline \multirow{2}{*}{ Study year } & \multirow{2}{*}{$\begin{array}{c}\text { No. } \\
\text { censuses }\end{array}$} & \multirow{2}{*}{ Total groups } & \multirow{2}{*}{$\begin{array}{l}\text { Groups/ } \\
\text { census }\end{array}$} & \multicolumn{3}{|c|}{ Group size } & \multirow{2}{*}{$\begin{array}{c}\% \\
\text { Immatures }\end{array}$} \\
\hline & & & & Mean & SD & Range & \\
\hline 2004 & 11 & 11 & 1 & 21.4 & 3.3 & $18-30$ & 0.38 \\
\hline 2006 & 12 & 12 & 1 & 17.3 & 1.5 & $15-19$ & 0.31 \\
\hline 2007 & 10 & 10 & 1 & 16.6 & 3.6 & $10-21$ & 0.35 \\
\hline 2008 & 10 & 9 & 0.9 & 4.4 & 0.8 & $3-5$ & 0 \\
\hline 2009 & 11 & 4 & 0.4 & 5.5 & 1.7 & $4-7$ & 0.39 \\
\hline 2010 & 11 & 5 & 0.4 & 5 & 0 & 5 & 0.4 \\
\hline Total & 65 & 51 & & & & & \\
\hline
\end{tabular}


FIGURE 2: Frequency distribution of group size of Tursiops truncatus in the Cagarras Archipelago between 2004 and 2006 to 2010.

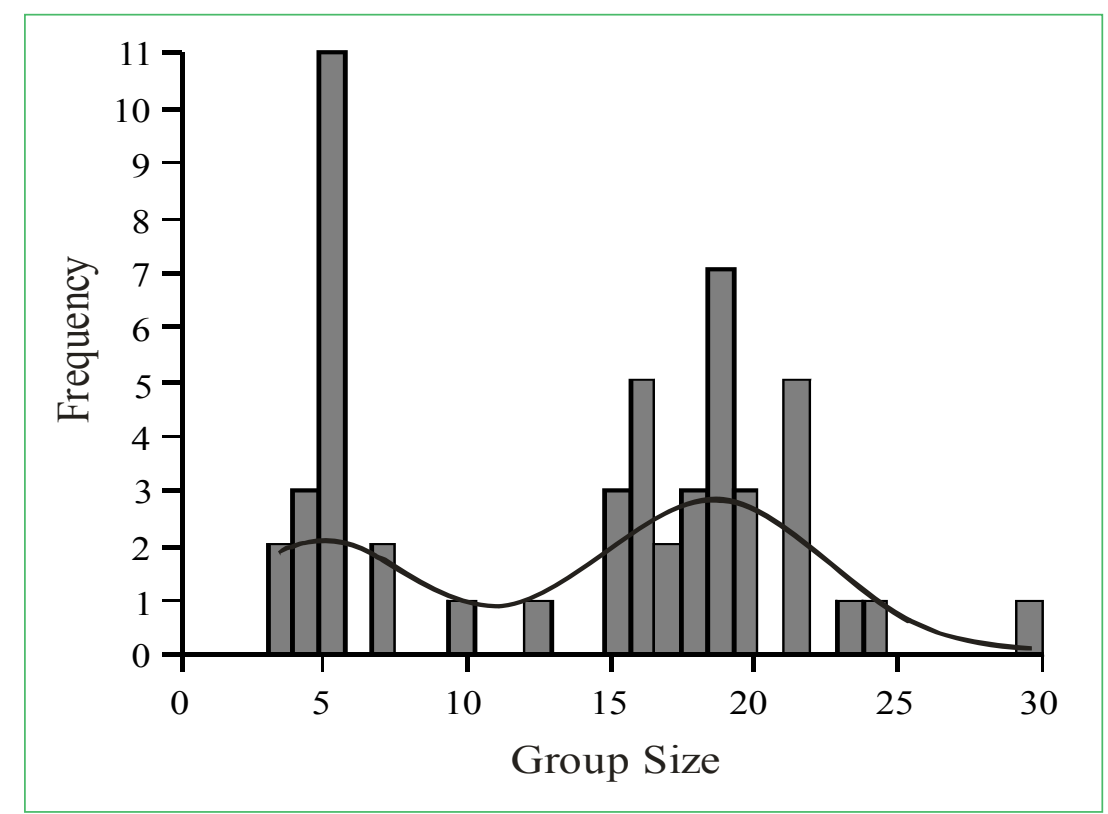

FIGURE 3: Linear regression of the group size of Tursiops truncatus in the Cagarras Archipelago on the year of observation from 2004 through 2010 .

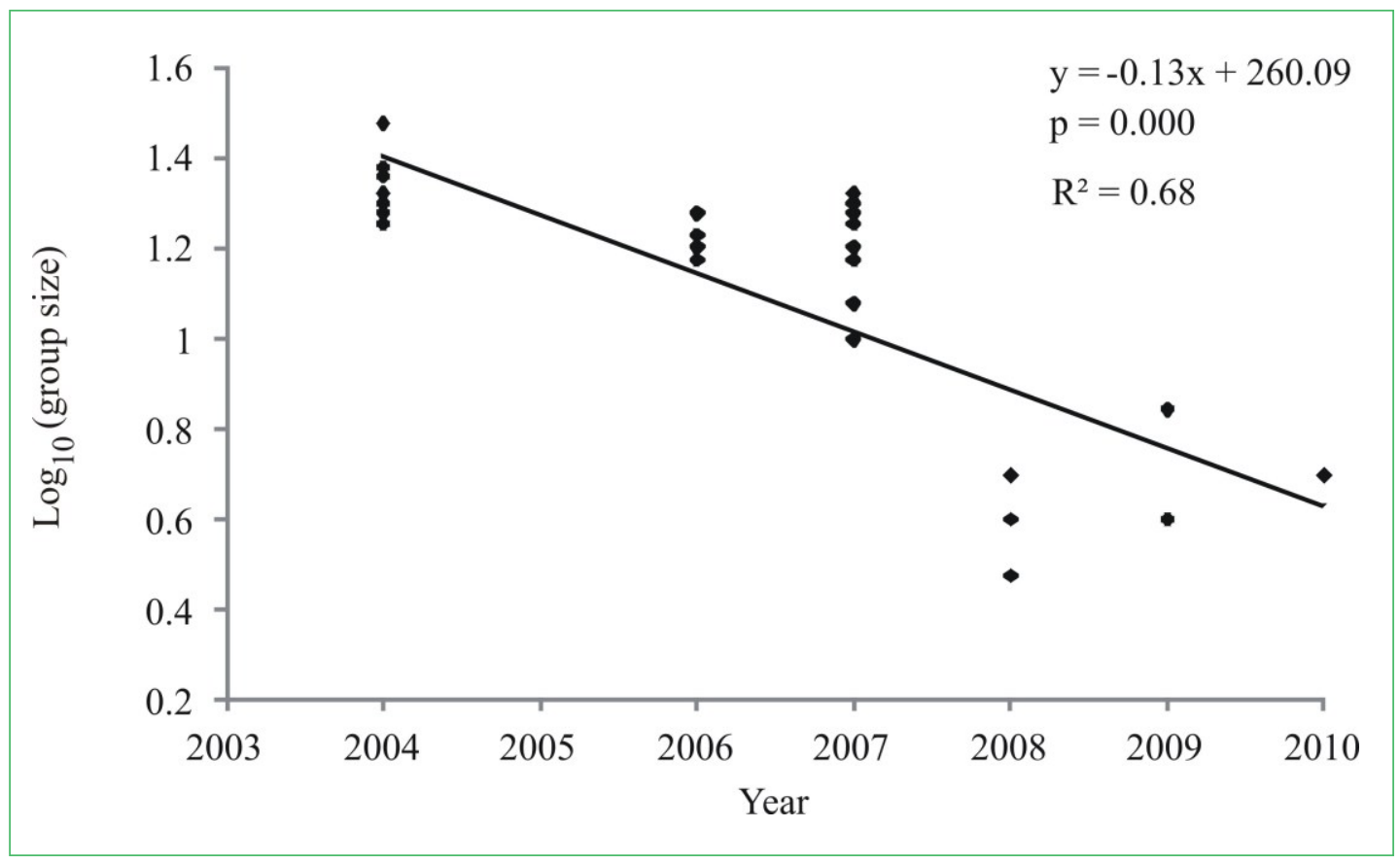


juveniles over the entire study. The average number of immature individuals in relation to the total group size varied between 0.31 (2006) and 0.4 (2010) (Table 1), and the differences between years were non significant (Kruskal-Wallis: $\left.\mathrm{H}_{(4, \mathrm{~N}=42)}=1.48, \mathrm{p}=0.83 \mathrm{~ns}\right)$.

\section{Discussion}

Barbosa et al. (2008) reported that in 18 observations made between June and December of 2004 and 2005 in the Cagarras Archipelago, the group size ranged from three -20 individuals (mean 13). This report agrees with the results obtained in this study. Although group size varies according to the biogeographical region, the average sizes recorded in the present study are typical of T. truncatus groups in coastal waters (e. g. BEARZI et al., 1997; DEFRAN; WELLER, 1999; MAZE-FOLEY; WÜRSIG, 2002; LUSSEAU et al., 2003) despite the inherent differences among the residency patterns in a restricted area.

The variation in group size observed in this study especially after 2008 may be a consequence of one or more of the following factors: (a) the flexible and highly adaptable behavior of the species (SHANE et al., 1986; BEARZI et al., 2008); (b) the fluid nature of a fission-fusion society that undergoes frequent changes in group size, composition and social relationships (see BEARZI et al., 1997; CONNOR et al., 2000 and references therein); (c) the irregular distribution of prey items in coastal habitats (WELLS et al., 1987; DEFRAN; WELLER, 1999); and (d) the decrease in biological diversity within the archipelago due to human-induced stresses (RANGEL et al., 2007; ECOMAR/SEAP, 2009). During the censuses, the observed groups often formed small ephemeral subgroups whose composition changed frequently (i.e., the groups showed the fission-fusion behavior) (LODI, 2009). However the decline in group size shows negative trend in seasonal abundance. This trend may be directly or indirectly linked with factors (c) and (d) cited above. Shane et al. (1986), Santos and Lacerda (1987), and Bearzi et al. (1997; 2008) reported that the lowest densities of common bottlenose dolphins were correlated with habitat quality determined by a loss of biodiversity and/or degradation of the marine environment. The proximity of the site to shore results a greater influence of land-based activities, including sewage discharge (CARREIRA; WAGENER, 1998). In addition, the archipelago is influenced significantly by the eutrophic waters of Guanabara Bay (SisBAHIA, 2011). The site is also easily accessed by boat from of Rio de Janeiro. For example, on weekends we recorded as many as 40 boats moored within or moving around the archipelago. The use of the area by boats is of particular concern because most groups observed during the study include neonates, calves and juveniles. Yachts and jet skiers have been observed to make rapid approaches to the dolphins and members of the public have been observed attempting to swim assertively with the dolphins. The drastic reduction in group size since 2008 may be a lagged response to the cumulative impacts of multiple human activities in coastal areas. Unfortunately, there is little scientific information available to date test this hypothesis.

The observed group composition indicates that the protected and shallow waters $(\leq 18 \mathrm{~m})$ of the inner Cagarras Archipelago may be used during the austral winter and spring as a nursery or calving ground. The archipelago is the best protected group of islands in the city of Rio de Janeiro. In this context, earlier observations in the archipelago based the history of capture and recapture of the video images of individually identified animals (LODI, 2009) have shown that the period of mother-infant bonding spans two to three years. This result is consistent with previous reports (WELLS et al., 1987; WELLS, 1991; BEARZI et al., 1997) and supports the idea that the archipelago might be used during a particular time of the year as a calf-rearing area, specifically for nursing and for protection to minimize the risk of predation. The constancy over the years of the average number of immature individuals relative to the total group size reinforces this assumption. Indeed, detailed studies of females Indo-Pacific bottlenose dolphins (T. aduncus) in Shark Bay, Australia, have indicated that reproductive success is correlated with the presence of sheltered and shallow waters that provide a favorable environment for raising calves (MANN et al., 2000).

The reasons for the use of the Cagarras Archipelago during only a particular time of the year are not clear. The 
area or areas from which these animals initially travel to the archipelago and the area or areas to which they travel after they leave the archipelago are still unknown. Photoidentification studies that include a broader geographical area could provide insights into this problem.

The dynamics of these small coastal groups appear to be considerably different from those of the well-established resident populations of the southern Brazilian coast (e. g., SIMÕES-LOPES; FÁBIAN, 1999; MATTOS et al., 2007). The results reported here have important implications regarding management priorities for the protection of T. truncatus in the Cagarras Archipelago. Measures limiting fishing activities and regulating marine traffic for all categories of vessels in the area are essential for inclusion in the management plan for this marine protected area.

\section{Acknowledgements}

The authors wish to thank Sheila M. Simão, Paulo César Simões-Lopes, Artur Andriolo and two anonymous reviewers for their suggestions for improving the manuscript. We express our gratitude to Sérgio C. Moreira, for providing the Figure 1. CNPq provided a Research Productivity Fellowship for C. Monteiro-Neto.

\section{References}

BARBOSA, M. M. C.; CRUZ, F. S.; LODI, L. Comportamento e organização de grupo do golfinho-nariz-de-garrafa, Tursiops truncatus (Cetacea, Delphinidea) no arquipélago das Cagarras, Rio de Janeiro. Revista Brasileira de Zoociências, Juiz de Fora, v. 10, n. 3, p. 211-218, 2008.

BEARZI, G.; NOTARBARTOLO-DI-SCIARA, G.; POLITI, E. Social ecology of bottlenose dolphin in the Kvarneric (Northern Adriatic Sea). Marine Mammal Science, Lawrence, v. 13, n. 4, p. 650-668, 1997.

BEARZI, G.; FORTUNA, C. M.; REEVES, R. R. Ecology and conservation of common bottlenose dolphins Tursiops truncatus in the Mediterranean Sea. Mammal Review, Bristol, v. 39, n. 2, p. 92-123, 2008.

BRÄGER, S.; WÜRSIG, B.; ACEVEDO, A.; HENNINGSEN, T. Association patterns in bottlenose dolphins in Galveston Bay, Texas. Journal of Mammalogy, Lawrence, v. 75, n. 2, p. 431-437, 1994.

BREDER, C. M. Equations descriptive of fish schools and other animal aggregations. Ecology, New York, v. 35, n. 3, p. 361-370, 1954.
CAMPBELL, G. S.; BILGRE, B. A.; DEFRAN, R. H. Bottlenose dolphins (Tursiops truncatus) in Turneffe Atoll, Belize: Occurrence, site fidelity, group size, and abundance. Aquatic Mammals, Macomb, v. 28, n. 2, p. 170-180, 2002.

CARREIRA, R. S.; WAGENER, A. L. Speciation of sewage derived phosphorus in coastal sediments from Rio de Janeiro, Brazil. Marine Pollution Bulletin, Amsterdam, v. 36, n. 10, p. 818-827, 1998.

CONNOR, R. C.; WELLS, R. R.; MANN, J.; READ, A. J. The bottlenose dolphin: social relationships in a fission-fusion society. In: MANN, J.; CONNOR, R. C.; TYACK, P.; WHITEHEAD, H. (Ed.). Cetacean societies: Field studies of dolphins and whales. 1 ed. New York: University of Chicago Press, 2000. p. 91-126.

DEFRAN, R. H.; WELLER, D. Occurrence, distribution, site fidelity, and school size of bottlenose dolphins (Tursiops truncatus) off San Diego, California. Marine Mammal Science, Lawrence, v. 15, n. 2, p. 366-380, 1999.

DI BENEDITTO, A. P. M.; RAMOS, R. M. A.; SICILIANO, S.; SANTOS, R. A.; BASTOS, G.; FAGUNDES-NETO, E. Stomach contents of delphinids from Rio de Janeiro, southeastern Brazil. Aquatic Mammals, Macomb, v. 27, n. 1, p. 24-28, 2001.

ECOMAR/SEAP - SECRETARIA ESPECIAL DE AQUICULTURA E PESCA. Caracterização da atividade pesqueira no entorno das Ilhas Cagarras, Rio de Janeiro - RJ: informações para a criação de uma unidade de conservação. Convenio SEAP no 045/07. Processo no 00.350.003405/2007-12. Cidade: Editora, 2009. 274 p.

FLORES, A. P.; FONTOURA, N. F. Ecology of marine tucuxi, Sotalia guianensis, and bottlenose dolphin, Tursiops truncatus, in Baía Norte, Santa Catarina State, Southern Brazil. The Latin American Journal of Aquatic Mammals, Rio de Janeiro, v. 5, n. 2, p. 105-115, 2006.

FORTUNA, C. M. Ecology and conservation of bottlenose dolphins (Tursiops truncatus) in the north-eastern Adriatic Sea. 2006. 256 f. Thesis (Philosophy) - University of St. Andrews, St Andrews. 2006.

GEISE, L.; BOROBIA, M. Sobre a ocorrência de cetáceos no litoral do estado do Rio de Janeiro, entre 1968 e 1984. Revista Brasileira de Zoologia, Curitiba, v. 4, n. 4, p. 341-346, 1988.

GOWANS, S.; WÜRSIG, B.; KARCZMARSKI, L. The social structure and strategies of delphinids: Predictions based on an ecological framework. Advances in Marine Biology, Plymouth, v. 53, p. 195-294, 2008.

GYGAX, L. Evolution of group size in the dolphins and porpoises: Interspecific consistency of intraspecific patterns. Behavioral Ecology, Oxford, v. 13, n. 5, p. 583-590, 2002.

LODI, L. Fidelidade de área, características de grupo e organização social de Tursiops truncatus (Cetacea, Delphinidade) no Arquipélago das Cagarras, Rio de Janeiro, RJ, Brasil. 2009. 277 f. Tese (Doutorado em Biologia Marinha) Universidade Federal Fluminense, Niterói. 2009.

LODI, L.; WEDEKIN, L. L.; ROSSI-SANTOS, M. R.; MARCONDES, M. C. Movements of the bottlenose dolphins (Tursiops truncatus) in the Rio de Janeiro State, Southeastern Brazil. Biota Neotropica, Campinas, v. 8, p. 205-209, 2008.

LUSSEAU, D.; SCHNEIDER, K; BOISSEAU, O. J.; HAASE, P.; SLOOTEN, E.; DAWSON, S. M. The bottlenose dolphin 
community of Doubtful Sound features a large proportion of longlasting associations. Can geographic isolation explain this unique trait? Behavioral Ecology and Sociobiology, Gottingen, v. 54, n. 4, p. 396-405, 2003.

MANN, J.; SMUTS, B. Natal attraction: allomaternal care and mother-infant separations in wild bottlenose dolphins. Animal Behaviour, St Andrews, v. 55, n. 5, p. 1097-1113, 1998.

MANN, J.; CONNOR, R. C.; BARRE, L. M.; HEITHANUS, M. R. Female reproductive success in bottlenose dolphins (Tursiops sp.): life history, habitat, provisioning, and group-size effects. Behavioral Ecology, Oxford, v. 11, n. 2, p. 210-219, 2000.

MATTOS, P.; DALLA-ROSA, L.; FRUET, P. Activity budgets and distribution of bottlenose dolphin (Tursiops truncatus) in the Patos Lagoon Estuary, South Brazil. The Latin American Journal of Aquatic Mammals, Rio de Janeiro, v. 6, n. 2, p. 161-169, 2007.

MAZE-FOLEY, K.; WÜRSIG, B. Patterns of social affiliation and group composition for bottlenose dolphins (Tursiops truncatus) in San Luis Pass, Texas. Gulf of Mexico Science, Alabama, v. 20, n. 2, p. 122-134, 2002.

OLIVEIRA, S. V. C.; CARVALHO, H. A.; MOREIRA, S. C.; CORDEIRO, A. S. Ocorrência de mamíferos marinhos em Guaratiba e Marambaia, Rio de Janeiro. Bioikos, Campinas, v. 8, n. 1-2, p. 20-29, 1994.

OVIEDO, L.; SILVA, N. Sighting frequency and relative abundance of bottlenose dolphins (Tursiops truncatus) along the northeast coast of Margarita Island and Los Frailes Archipelago, Venezuela. International Journal of Tropical Biology, São José, v. 53, n. 3-4, p. 595-600, 2005.

PARRISH, J. K.; EDELSTEIN-KESHET, L. Complexity, pattern, and evolutionary trade-offs in animal aggregation. Science, New York, v. 5411, n. 284, p. 99-101, 1999.

QUINTANA-RIZZO, E.; WELLS, R. S. Resighting and association patterns of bottlenose dolphins (Tursiops truncatus) in Cedar Keys, Florida: insights into social organization. Canadian Journal of Zoology, Montreal, v. 79, n. 3, p. 447-456, 2001.

RAMOS, R.; POLETTO, F.; MOREIA, S.; ERBER, C.; DAFFERNER, G.; FREITAS, R.; FIGNA, V.; MIRANDA, C.; ALENCASTRO, P.; CARNEIRO, A.; FORTES, R.; RINALDI, G.; DEMARI E SILVA, E.; BARBOSA, M. Família Delphinidade: outros pequenos golfinhos. In: RAMOS, R. M. A., SICILIANO, S.; RIBEIRO, R. (Orgs.). Monitoramento da biota marinha em navios de sísmica: seis anos de pesquisa (2001-2007). 1 ed. Vitória: Everest Tecnologia em Serviços / PGS Investigação Petrolífera Ltda., 2010. p 649-728.
RANGEL, C. A.; CHAVES, L. C.; MONTEIRO-NETO, C Baseline assessment of the reef fish assemblage from Cagarras Archipelago, Rio de Janeiro, Southeastern Brazil. Brazilian Journal of Oceanography, São Paulo, v. 55, n. 1, p. 7-17, 2007.

SANTOS, M. E.; LACERDA, M. Preliminary observations of the bottlenose dolphin (Tursiops truncatus) in the Sado estuary (Portugal). Aquatic Mammals, Macomb, v. 13, p. 65-80, 1987.

SHANE, S. Residence patterns, group characteristics, and association patterns of bottlenose dolphins near Sanibel Island, Florida. Gulf of Mexico Science, Alabama, v. 22, n. 1, p. 1-1, 2004. SHANE, S. H.; WELLS, S.; WÜRSIG, B. Ecology, behavior and social organization of the bottlenose dolphin: a review. Marine Mammal Science, Lawrence, v. 2, n. 1, p. 34-63, 1986.

SICILIANO, S., RAMOS, R. M. A; DI BENEDITTO, A. P. M.; SANTOS, M. C. O.; FRAGOSO, A. B.; BRITO JR., J.; AZEVEDO, A. F.; VICENTE, A. F. C.; ZAMPIROLLI, E.; ALVARENGA, F. S.; BARBOSA, L.; LIMA, N. R. W. Age and growth of some delphinids in south-eastern Brazil. Journal of the Marine Biological Association of the United Kingdom, Plymouth, v. 87, n. 1, p. 293-303, 2007.

SIMÕES-LOPES, P. C.; FÁBIAN, M. E. Residence patterns and site fidelity in bottlenose dolphins, Tursiops truncatus (Montagu) (Cetacea, Delphinidae) of Southern Brazil. Revista Brasilera de Zoología, Curitiba, v. 16, n. 4, p.1017-1024, 1999.

SisBAHIA. Sistema de Base Ambiental de Hidrodinâmica Ambiental. 2011. Disponível em $<$ http://www.sisbahia.coppe.ufrj. br>. Acesso em: 7 jul. 2011

STATSOFT, Inc. (2004). STATISTICA (Data Analysis Software System). Version 7.0. 2004. Disponível em $<$ http://www.statsoft. com>. Acesso em: 3 janeiro 2011.

WEDEKIN, L. L.; DAURA-JORGE, F. G.; ROSSI-SANTOS, M. R.; SIMÕES-LOPES, P. C. Notas sobre a distribuição, tamanho de grupo e comportamento do golfinho Tursiops truncatus (Cetacea: Delphinidae) na Ilha de Santa Catarina, sul do Brasil. Biota Neotropica, Campinas, v. 8, n. 4, p. 225-229, 2008.

WELLS, R. S. The role of long-term study in understanding the social structure of a bottlenose community. In: PRYOR, K.; NORRIS, K (Eds.). Dolphin societies: discoveries and puzzles. 1 ed. Los Angeles: University of California Press, 1991. p. 199-225.

WELLS, R. S.; SCOTT, M. D.; IRVINE, A. B. The social structure of free-ranging bottlenose dolphins. In: GENOWAYS, H. H. (Ed.). Current mammalogy. New York: Plenum Press, 1987. p. 247-303. 